\title{
A study on relationship among free cash flow, firm value and investors' cautiousness: Evidence from Tehran Stock Exchange
}

\author{
Hassan Ghodrati ${ }^{\mathrm{a}^{*}}$ and Abbas Hashemi
}

Department of Management and accounting, Kashan Branch, Islamic Azad University, Tehran, Iran

\section{H R O N I C E E A B S T R A C T}

Article history:

Received January 20, 2014

Accepted 5 July 2014

Available online

August 182014

Free Cash Flow

Real Firm Value

Predicted Firm Value

Capital Cost

\section{Introduction}

Free cash flow is a metric to measure the performance of most firms and represents the cash that the company would have after paying expenses necessary to maintain and to develop assets. Therefore, free cash flow is very important because it allows firms to seek opportunities to increase share value. Having no cash will make many measures impossible including new product development, having business achievement, paying cash benefits to shareholders and debt relief. On the other hand, cash should be kept at a level appropriate to balance cash costs and insufficient cash costs. Given the findings, the capital market is a very high discount rate, which neutralizes future profits in calculating the value of enterprise. Namely, future cash flows discounted rate is so high that most of future cash flows are disregarded practically. This is in conflict with what many claim as "A firm value equals a current discounted value of future cash flows" (Platt, et al., 2010). In this study, we seek to investigate this claim as to whether or not companies have more value than what the market believes.

*Corresponding author

E-mail addresses: dr.ghodrati42@google.com (H. Ghodrai)

(C) 2014 Growing Science Ltd. All rights reserved.

doi: $10.5267 / \mathrm{j} . \mathrm{ms} 1.2014 .8 .021$
Financial statements as well as financial standards are always considered as primary sources for getting rich information of firms. The standards are normally divided in two categories of economic and accounting and each of these standards shows one of the specifications of the company and has its own advantageous and disadvantageous. There are different standards, more change to succeed in attracting credits and financing from the capital market. Under such circumstances, such a company can attract more finance and it can be sold sooner on the stock exchange. This paper tries to investigate on the free cash flow as an effective factor in Exchange. The results of this study have disclosed that, there was a direct and meaningful relationship between free cash flow of the business enterprises and their real values. Second, the real values of the business enterprises are more than their predicted values. Finally, the predicted value of the business enterprises on the basis of the free cash flow is more than their market value. 


\section{Literature review}

Jaggi and Gul (2005) believed it is difficult to calculate free cash flow based on the Jensen model because it cannot detect all valuable projects rapidly with positive net present and expected value of an enterprise. In addition, there may be no reliable information of setting rate of capital cost. In this regard, we tried to use other models that are alternatives of Jensen model for calculation of free cash flow in an enterprise. Lehn and Poulsen (1989) defined the free cash flow as operating profit before depreciation cost after deducting the payments for taxes, interest fees, and dividends of preferred and common shareholders. Copeland (1994) defined the free cash flows of enterprises as operating profit after taxes plus non-cash expenses after deducting investment of working capital, properties, machinery, equipment and other assets. Rezvani et al. (2009) examined the relationship among different components of free cash flow on selected firms listed on Tehran stock exchange. Their results showed that there was a significant positive relationship between free cash flow and direct changes of dividends in large firms and those having lower investment opportunities.

Izadinia et al. (2008) examined the relationship between economic value added of, earnings per share and cash flows with annual returns of listed companies of 52 companies listed in Tehran stock exchange over the period 1999-2003 and reported that there was a significant relationship between variables. Others examined the relationship between profits as a part of operating cash flows and change of share value and reported a significant positive relationship between different variables. Tehrani and Seraji (2009) investigated the relationship between economic value added, cash flow from operating activities and profits before interest and tax with market value of listed companies in Iran stock exchange. Rahmani and Tahany (2007) examined the ability of financial statements items in forecasting future cash flows. Results showed that operating profit, changes of accruals items and cash parts and historical cash flow could forecast future cash flow resulted from. Molaii and Khani(2009) investigated the relationship between accounting profit and operating cash flow with systematic risk in Tehran Stock Exchange. They showed that mentioned items had relative information content.

Sheri (2007) examined the relationship of different profits and cash flows with stock return in a sample of listed companies in Iran stock exchange over the period 2001-2005. Their results showed that the correlation between stock returns and profits with increasing accruals or deferred ones to the correlation of cash flows with stock returns could be increased. Khodadi and Jalali (2007) examined the ability to forecast future cash flows using previous cash flow and accruals of earnings over the period 2001-2006. They showed that adding accruals of earnings to cash flow model would increase the forecasting power of this model.

Tehrani and Hesarzade (2009) examined the impact of free cash flows and constraints in financing on investment in Tehran Stock Exchange over the period 2000-2006. They showed that there was a direct significant relationship between free cash flows and more investment statistically. Mehrani and Bagheri (2009) investigated the impact of free cash flows and institutional shareholders on profit management of listed companies in Tehran stock exchange over the period 1999-2005. Results showed that there was a direct significant relationship between profit management and free cash flow in companies with low growth but there was no significant relationship between profit management and institutional shareholders in companies with high free cash flow and low growth. Griffin et al. (2010) examined the relationship between free cash flow, problems related to agency and audit fees in the United States of America. They showed that companies with high FCF and high production growth had higher audit fees. Lally (2008) investigated the relationship between free cash flow, the final value and timing and the replacement of properties. They showed that the wrong performance leads to creating error in valuation In addition, the financial statements that are prepared based on property valuation and replacement cost, were better than those based on the evaluation of market prices. Pareja (2010) examined the relationship between capital cost and free cash flow. They showed 
that calculating the weighted average cost of capital (WACC) was independent of free cash flow (CFC). Additionally, FCF affects WACC. Fuller and Kathleen (2010) studied the relationship between free cash flow and non-uniform dividends. They showed that companies having higher quality, would pay dividends to eliminate the problems associated with free cash flow, while other companies having lower quality could pay dividends to earn money in the future and to reduce the problems associated with free cash flow. Gregory and Wang (2013) studied the relationship between free cash flow, corporate ownership and debt on the long-term performance. They showed that low ratio of debt to net assets and high FCF could have benefits for monitoring and controlling shareholders. Byrd (2010) investigated the relationship between financial policies and brokerage fees of free cash flow in oil industry. He indicated that the estimated brokerage fees had an inverse relationship with financial power that this was consistent with the effects of controlling debts.

\section{Research questions}

Based on description research methodology, in the present investigation we considered to answer the following questions:

Main question: What is the relationship between the value of enterprise and real free cash flows?

\section{Sub-questions:}

1. What is the relationship between firm value and free cash flow?

2. What is the difference between the real firm value and its market value?

3. What is the difference between the predicted firm value based on the free cash flow and market value?

\section{Research methodology}

In this study, listed companies in Tehran Stock Exchange were defined as statistical sample. The study excluded investment companies and financial brokerage because of their low activities in this market. Among them, 56 companies were selected as sample by using stratified random sampling and based on Cochran formula and the study has been accomplished over the period 2007-2012. Depending on the case, descriptive tests including mean, variance, standard deviation and scattering plots have been used to describe the data. We used Kolmogrove-Simrnove test to evaluate suitability of the estimated relationship between the variables. The study also uses variance analysis along with student t-test to generalize results of random sample to statistical population. For each year of companies in the sample, we calculate the following variables,

$\mathrm{EV}=$ Cash - Debt + Market capitalization, $\mathrm{WC}=$ Documents + Cash - Net current assets, $\mathrm{D}=\mathrm{Short}-$ term + long-tem, $\mathrm{MV}=$ Stock market price $\times$ number of shares.

where $E V$ is enterprise value, $W C$ is working capital, $D$ is debt and $M V$ is market value. In addition, WC (working capital) and the deferred taxes are calculated. The main difficulty in the calculation of free cash flow is capital cost of each firm. Firm value is determined based on the CAPM model as follows:

CAPM: $\mathrm{E}\left(R_{i}\right)=\left\lceil R_{f}+\beta_{i}\left(R_{m}-R_{f}\right)\right\rceil, \operatorname{Re}=\frac{D I V_{0}(1+g)}{P_{0}}+g$

$\mathrm{CCF}=\mathrm{Net}$ interest $+\Delta$ deferred taxes $+\Delta \mathrm{WC}$ - capital expenditures - depreciation + net income

$$
E E V=\sum_{i=1}^{y}\left(C C F_{i, j}\right) /\left(1+k_{j}\right)^{i}+T V_{j} /\left(1+k_{j}\right)^{y}
$$


where, $k$ is capital expenditures, $T V$ is final value, $i$ is year, $y$ is final year with cash flow data and $j$ indicates the firm with $\mathrm{EV}=$ capital market + debt-cash.

\section{Findings}

We describe the statistical findings based on the calculation of statistical indicators and results have been summarized in Table 1:

\section{Table 1}

Summary of Description Results

\begin{tabular}{lcccccc}
\hline Variable & Minimum & Maximum & Mean & St. Deviation & skewedness & Kurtosis \\
\hline EV & 39053 & 30397127 & 2126271.29 & 4807184.790 & 4.480 & 22.913 \\
EEV & 10292 & 33740531 & 1189494.80 & 4538095.950 & 6.987 & 50.556 \\
Sales & 12322 & 24066626 & 844759.41 & 3228709.528 & 7.036 & 51.128 \\
Assets & 17986 & 23688837 & 1028356.86 & 3184892.153 & 6.819 & 48.847 \\
\hline
\end{tabular}

This study follows a similar investigation of the combined linear regression to assess the relationships between variables. The method is based on assumptions such as normal distribution of variables, etc. that have been studied in this part. The normality test has been accomplished using KolmogorovSmirnov test and in cases where the assumption of normal distribution was rejected we used the logarithmic transformation for the variable for normalization. Results of Kolmogorov test for independent and dependent variables are summarized in Table 2 as follows,

Table 2

Summary of results of normality test of variable distribution

\begin{tabular}{llllll}
\hline Description & & EV & EEV & SALES & ASSETES \\
\hline Normal parameters & Average & 2072779 & 3591210 & 1251248 & 1582459 \\
& Standard deviation & 5209189 & 1504235 & 5056221 & 4890764 \\
\hline The difference between & Absolute & 0.348 & 0.406 & 0.403 & 0.375 \\
an upper bound & Positive & 0.328 & 0.377 & 0.392 & 0.339 \\
& Negative & 0.348 & 0.406 & 0.403 & 0.375 \\
\hline Kolmogorov - Smirnov Z & & 5.821 & 6.792 & 6.743 & 6.267 \\
Significance level. & & 0.00 & 0.00 & 0.00 & 0.00 \\
\hline
\end{tabular}

Based on the results listed in Table 2, the significance level for all variables is less than 0.05. Therefore, the null hypothesis was rejected and none of variables followed normal distribution. In addition, P-P Plot for the variables are plotted, which represents the net difference of points from 45 degrees bisector and thus non-normality of variables distribution. Fig. 1 summarizes the results.
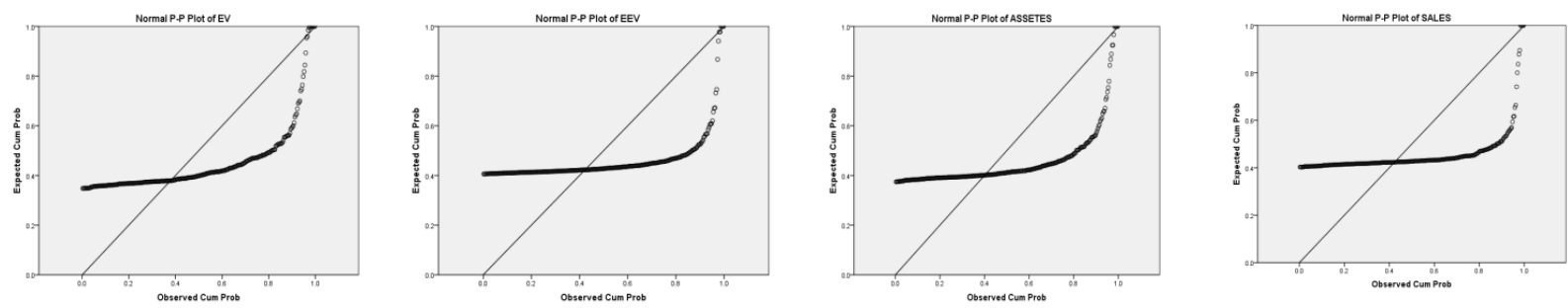

Fig. 1. The results of observed cumulative probability

To normalize the data, we have used the logarithmic transformation. Again, after normalization, we investigated the normality of transformed variables distribution using the Kolmogorov test summarized in Table 3 as follows: 
Table 3

Summary of results for normality test of transformed variables

\begin{tabular}{|c|c|c|c|c|c|}
\hline \multicolumn{2}{|l|}{ Variable } & Real value of firm EV & Free Cash Flow EEV & SALES & ASSETES \\
\hline \multicolumn{2}{|l|}{ Number } & 280 & 280 & 280 & 280 \\
\hline \multirow{2}{*}{$\begin{array}{l}\text { Normal } \\
\text { parameters }\end{array}$} & Average & 5.9020023 & 5.9395706 & 5.5444323 & 5.7396245 \\
\hline & Standard deviation & 0.53954730 & 0.62230836 & 0.54719140 & 0.54340570 \\
\hline \multirow{3}{*}{$\begin{array}{l}\text { The difference } \\
\text { between an upper } \\
\text { bound }\end{array}$} & Absolute & 0.051 & 0.044 & 0.091 & 0.066 \\
\hline & Positive & 0.051 & 0.044 & 0.091 & 0.066 \\
\hline & Negative & 0.049 & 0.037 & 0.075 & .056 \\
\hline \multicolumn{2}{|c|}{ Kolmogorov - Smirnov Z } & 0.851 & 0.739 & 1.515 & 1.112 \\
\hline \multicolumn{2}{|l|}{ Significance level. } & 0.464 & 0.646 & 0.020 & 0.169 \\
\hline
\end{tabular}

Based on the results listed in Table 3, the significance level for variables of EV and EEV that are the main variables of this study is greater than 0.05 and the normality hypothesis of transformed variables is confirmed. Based on Fig. 2, the comparison between the real and predicted observations is compatible with $45^{\circ}$ bisector and we can accept the normality hypothesis:
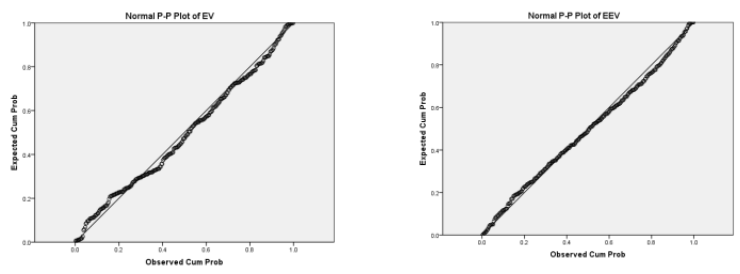

Fig. 2. PP Plot of normalized variables
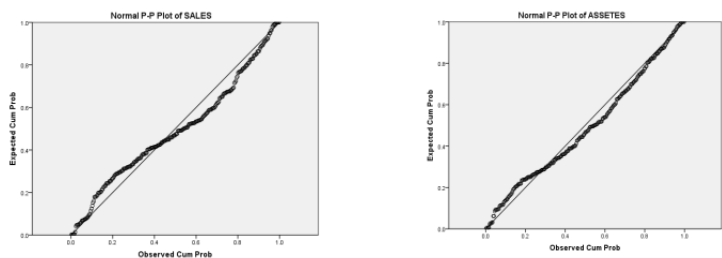

To check the homogeneity of variance, the parallel axes graphs are used. In this graph, the time series of real firm values of all selected companies are plotted in a graph. By observing the response fluctuations in different time periods on axes parallel to the Y axis, it is possible to have a general idea of homogeneity of variance or lack of it. Fig. 3 evaluated the homogeneity of variance based on parallel graphs:

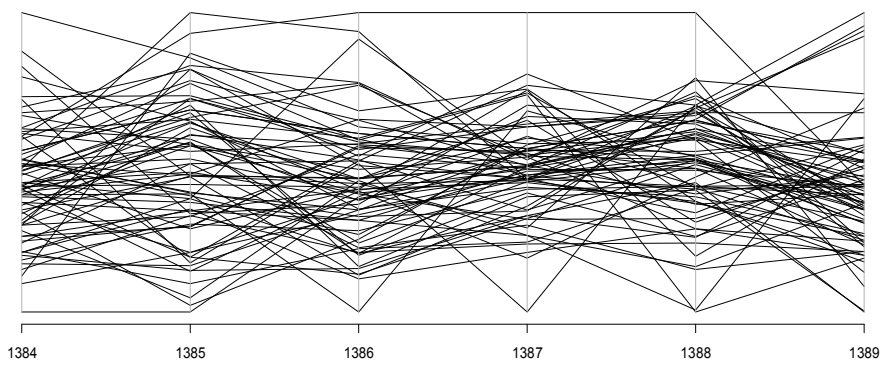

Fig. 3. Homogeneity of variance

As can be seen in Fig. 3, the dispersion of observations is the same almost in all years of research (distribution lines on the axes parallel to $\mathrm{Y}$ axis). Therefore, we can assume that the variance of the response variable is constant and does not change with time. Other assumption is to use combined linear regression in order to evaluate linear independence of the independent variables if we have high regression, this means there is a high correlation between these variables and they may have a high coefficient of determination but the model is not very valid. To check the linear independence, the statistical variance inflation factor is used and the results are summarized in Table 4: 
Table 4

Test results of the linear independence of the independent variables

\begin{tabular}{lccccccc}
\hline Parameter & B & St. & Beta & t statistic & Sig. level. & \multicolumn{2}{c}{ Variance inflation factor statistics } \\
& & & & & & & Tolerances \\
Constant & 0.670 & 0.145 & & 4.630 & 0.000 & & \\
Free Cash Flow & -0.145 & 0.47 & -0.168 & -3.119 & 0.002 & 0.210 & 4.773 \\
Sale & 0.146 & 0.50 & 0.146 & 2.853 & 0.005 & 0.231 & 4.327 \\
Assets & 0.923 & 0.50 & 0.930 & 18.634 & 0.000 & 0.243 & 4.111 \\
\hline
\end{tabular}

Tolerance values are used to show correlation between independence variables and they can be between 0 and 1 . When the ratio is close to zero, there is a strong relationship between these values and independent variables. The calculated values approach zero for co-linear tolerance and due to this linear independence of independent variables can be accepted. Variance inflation factor (VIF) is another factor to determine the linearity. The minimum value of this factor is one and this will be possible when there is no linear relationship between independent variables and the more is this value , it is much more indicative of co-linearity between independent variables. According to this study, it can be seen that the independent variables have a relative weak linear relationship with each other. We accepted the linear independence of the independent variables based on calculated VIF. One of the common problems in pattern regression is the correlation between residuals. In order to check the presence or absence of this problem we use Durbin-Watson test during which the desirable number has been optimized and eventually the autocorrelation problem among the residuals will be resolved. In this study, the evaluation of residual autocorrelation has been done based on Durbin-Watson statistic and results are summarized in Table 5:

Table 5

Evaluation of residuals autocorrelation

\begin{tabular}{lcccc}
\hline Parameter & R-Squared & Adjusted R-Squared & Standard error & Durbin-Watson statistic \\
\hline Amount & 0.883 & 0.831 & 0.221724 & 1.526 \\
\hline
\end{tabular}

Based on the results summarized of Table 5, according to the value of Durbin - Watson test statistic equals 1.526 and is between 1.5 and 2.5, it can concluded that observations are independent. Chow test is a test of equality between sets of coefficients in a two linear regression. This test is based on the sum of squared errors. To test the hypothesis, we estimated the effects of time constant and then evaluate the significant difference of structural changes test. This test is done to check for the presence of constant effects, and the results are summarized in Table 6:

Table 6

Results of chow test

\begin{tabular}{llll}
\hline Significant test & Statistics & Degrees of freedom & P-value \\
\hline Statistics F & 11.619093 & 4274 & 0.000 \\
Chi 2 & 43.870525 & 4 & 0.000 \\
\hline
\end{tabular}

As can be seen in Table 6 , with respect to P-value $<0.05$ was obtained based on the null hypothesis of intercept equality, it is rejected. Therefore, at this stage, we chose model of constant effects as the preferred model. Now we have to test constant effect model according to random effects model, which is accomplished through Housman test. This test with is used by Chi-Square test for comparing constant effects and random effects models in terms of explanatory power. In constant effects model, the intercepts are unknown but constant parameters but in random effects model, the intercept is random and independent of the explanatory variables. To do Housman test we used EVIEWS6 software. To do this test, first we should estimate the order- stochastic model. Housman test to check for random effects was performed and the results are summarized in Table 7: 
Table 7

Results of Housman test

Test Summary

Chi 2

degrees of freedom

$\mathrm{P}_{-}$value

Random variables

43.548902

1

0.000

As shown in Table 7, at a significance level of 5 percent, the null hypothesis is rejected based on the lack of relationship between individual effects and the explanatory variables. Hence, the $\mathrm{H}_{1}$ in Housman test is accepted as a question and in order to estimate the model we should use constant effects method. Assessing relationships between variables based on the following assumptions have been made based on following paragraphs:

\subsection{Relationship between firm value and free cash flow}

In order to investigate the relationship between free cash flow and the firm value over the period 2007-2012, Pearson correlation coefficient and combined linear regression were used. The results of correlation analysis are summarized in Table 8:

\section{Table 8}

Correlation Analysis of free cash flow and firm value

\begin{tabular}{lccccc}
\hline Parameter & 2008 & 2009 & 2010 & 2011 & 2012 \\
\hline R-Pearson & 0.803 & 0.823 & 0.735 & 0.784 & 0.772 \\
Sig. Level & 0.0000 & 0.0000 & 0.0000 & 0.0000 & 0.0000 \\
\hline
\end{tabular}

Based on the results of Table 8, it can be seen that the correlation coefficients approached 1 so there is a relative strong linear relationship between firm value and free cash flow during studied years. The positivity of coefficients show the directness of relationships between variables and approaching 0 supports the significance level of $95 \%$ generable to statistical population. Moreover, regarding the acceptance of assumptions, combined linear regression used by panel data and this is also used to check the relationship between variables. Regression estimation results are summarized in Table 9:

Table 9

Estimates of combined linear regression parameters

\begin{tabular}{llll}
\hline Variables & Regression coefficient & t-Statistic & Significance level. \\
\hline Constant & 0.357 & 0.796 & 0.430 \\
Free Cash Flow & 0.301 & 2.220 & 0.031 \\
Sale & 0.068 & 0.426 & 0.672 \\
Current assets & 0.622 & 3.403 & 0.001 \\
F-Statistic: 51.554 & Sig. : 0.000 & R-Square: 0.748 & \\
\hline
\end{tabular}

Placing parameters in the regression equation based on the results shown in Table 9, the relationship between the variables is expressed as follows:

$\mathrm{Y}=0.301 \mathrm{X}_{1}+0.622 \mathrm{X}_{3}+0.357$

where in this relationship, the dependent variable is firm value and independent variables include free cash flow and sales as a measure of firm size. The coefficient of determination indicates that this relationship is stated close to seventy-five percent of variables. Positive coefficients of the independent variables in this table indicate direct relationship between free cash flow and firm value. Approaching zero of significance level of Fisher test shows the relative strong significant relationship between firm value and free cash flow and sales at $\% 95$ confidence level. 
2008

The difference between real value and the market value of the company: to determine real firm value and its market value, the comparison test of means was used. First, mean and the variance of real values and market values have been calculated and they are summarized in the following Table 10:

\section{Table 10}

Statistical indicators of the real and market values

\begin{tabular}{llll}
\hline Variable & Average & Standard deviation & Standard error \\
\hline Real firm value & 20727792 & 20918985 & 3113086 \\
Market value of firm & 13033228 & 333738682 & 994471 \\
\hline
\end{tabular}

The results of Table 10 show that on average, real firm values are $30 \%$ more than market values. Due to using the random sample to generalize to the target population, difference test of means was used and the results are summarized in Table 11 as follows,

\section{Table 11}

Comparison of real firm value and market value of companies

\begin{tabular}{ccccc}
\hline Upper Limit & Lower Limit & Difference & Sig. Level & T Statistic \\
\hline 1495667 & 43245 & 769456 & 0.038 & 2.081 \\
\hline
\end{tabular}

The results of Table 11 show that there was a significant difference between real firm values and market values. Two last columns of table show the upper and lower confidence interval of the average difference between real firm value and market value of $95 \%$ level. Finally, in order to determine the difference between the predicted firm value with the market value, difference test of means was used. First, the mean and variance of the predicted and measured values and market values were calculated and are summarized in Table 12 as follows:

Table 12

Statistical indicators of predicted firm values and market values

\begin{tabular}{cccc}
\hline Variable & Average & Standard deviation & Standard error \\
\hline Predicted firm value & 3591210 & 15038120 th & 898,699 \\
Market firm value & 130,332 & 3337386 & 199447 \\
\hline
\end{tabular}

The results of Table 12 show that on average, the predicted firm values were significantly more than their market values. The average values of the two companies are expected to be much higher than its market value. Due to using the random sample to generalize to the target population, difference test of means was used and results are summarized in Table 13:

Table 3

Comparison of the predicted firm values and market values

\begin{tabular}{ccccc}
\hline Upper Limit & Lower Limit & Difference & Sig. Level & T Statistic \\
\hline 4096084 & 479,691 & 2287887 & 0.013 & 3.485 \\
\hline
\end{tabular}

The results of Table 13 show that regarding the significance level of less than $5 \%$, the assumption of equality of means is rejected. In other words, there is a significant difference between real firm values and market values. Two last columns of table show the upper and lower confidence interval of the average difference between real firm value and market value of $95 \%$ level.

\section{Conclusion}

In this study, 65 listed companies in Iran stock exchange were selected, randomly. Evaluation of the relationship between free cash flow and firm value of studied sample has been accomplished based on financial performance of the companies over the period 2008-2012. After evaluating statistical 
assumptions, the combined linear regression and difference test of means were used to examine relationships between variables. The results showed that:

1) There is a relative strong linear relationship between free cash flows and firm value.

2) The relationship between firm value and free cash flow is direct and firm value increases by increasing the free cash flows in companies and vice versa.

3) Difference test of means showed that there was a significant difference between real firm value and its market value. Investigation revealed that real firm values were much more than market values of companies.

4) Difference test of means showed that there was a significant difference between predicted firm value and its market value. Investigation revealed that predicted firm values were much more than market values of companies.

\section{References}

Arzac, E. R. (2005). Valuation for mergers, buyouts, and restructuring. Hoboken, NJ: Wiley.

Bayazidi, A., \& Jabbarzadeh Kangar luii, S. (2009). Evaluation and comparison of the explanatory power of EVA, residual income and abnormal growth of profit in determining market value of shares of companies listed in Tehran stock exchange. Quarterly Journal of Tehran Stock Exchange, 2(7), 133-159.

Byrd, J. W. (2010). Financial policies and the agency costs of free cash flow: evidence from the oil industry. Available at SSRN 1664654.

Campbell, J. Y., \& Shiller, R. J. (1988). Cointegration and tests of present value models.

Chen, K. C., Chen, Z., \& Wei, K. C. (2011). Agency costs of free cash flow and the effect of shareholder rights on the implied cost of equity capital. Journal of Financial and Quantitative Analysis, 46(01), 171-207.

Copeland Thomas, E., Koller, T., \& Murrin, J. (1994). Valuation: measuring and managing the value of companies/. Wiley frontiers in finance.

Darabi, R., Nouri Fard, Y., \& Esfandiari, E. (2007). The review of relationship between adjusted economic value added, profit before Interest and tax, cash flows of operating activities and market value of shares of food industry companies in listed companies in Tehran Stock Exchange. Master thesis, Science and Research university, Tehran, Iran.

Davari, M. R., Abzari, M., \& Afrasiabi, P. (2005). The review of relationship between firm size, net income growth and its capital costs among the listed companies in Tehran Stock Exchange. Master thesis, Business Administration, Allameh Tabatabai University.

Delshad, A. (2011). Stock valuation / Aswat Damodaran; Tehran publication, $1^{\text {st }}$ ed.

Esmaili, H. (211). The relationship between cash flow and net income (profit) of companies. Auditor magazine, 52.

Gapenski, L. C., \& Pink, G. H. (2003). Understanding healthcare financial management. AUPHA.

12. Fatma.bm, $(2,010)$ "Interactions Between Free Cash Flow, Debt Policy and Governance Structure" . working paper. www.ssrn.com

Fuller, K., \& Blau, B. M. (2010). Signaling, free cash flow and "nonmonotonic" dividends. Financial Review, 45(1), 21-56.

Gunasekaran, A., Patel, C., \& Tirtiroglu, E. (2001). Performance measures and metrics in a supply chain environment. International journal of operations \& production Management, 21(1/2), 71-87.

Gregory, A., \& Wang, Y. H. (2013). Cash acquirers: Can free cash flow, debt and institutional ownership explain long-run performance?. Review of Behavioral Finance, 5(1), 35-57. 
Griffin, P. A., Lont, D. H., \& Sun, Y. (2010). Agency problems and audit fees: further tests of the free cash flow hypothesis. Accounting \& Finance, 50(2), 321-350. 18. Hanifi, Farhad; Financial Management / Weston; Tehran Publications, 2nd Edition, 2007

Izadinia, N., Khani, A., \& Mullaii, M. (2007). The relationship between accounting earnings and operating cash flow with systemic risk in the Tehran Stock Exchange. Master's thesis, Science and Research university, Tehran

Izadinia, N., Foroughi, D., \& Torabi, M. H. (2008). Investigating the relationship between economic value added and earnings per share and cash flows with annual returns of companies listed in Tehran stock exchange. Master thesis, Science and Research university, Tehran.

Jaggi, B., \& Gul, F. A. (2005). Evidence of accruals management: A test of the free cash flow and debt monitoring hypotheses. Available at SSRN 2699.

Jensen, M. C. (1986). Agency costs of free cash flow, corporate finance, and takeovers. The American Economic Review, 76(2), 323-329.

Karpavicius, S., \& Yu, F. (2011). A Test of the Free Cash Flow Hypothesis: The Impact of Increased Institutional Holdings on Firm Characteristics.

Khodadadi vali, D. M., \& Jalali, A. (2007). Evaluation of the forecasting of future cash flows using the cash flow and accrual components of past returns. Master Thesis, Shahid Chamran Universityof ahvaz, Accounting research magazine.

Kimmel, P. D., Weygandt, J. J., \& Kieso, D. E. (2010). Financial accounting: Tools for business decision making. John Wiley \& Sons.

Lally, M. (2008). Free cash flow models, terminal values and the timing of asset replacements*. New Zealand Economic Papers, 42(1), 79-102.

Lehn, K., \& Poulsen, A. (1989). Free cash flow and stockholder gains in going private transactions. The Journal of Finance, 44(3), 771-787.

Maham, K. (2008). Model of free cash flow for shareholders. Journal of Accounting Research, 12.

Mehrani, S., \& Bagheri, B. (2009). Investigating the effects of free cash flows and institutional shareholders on profit management of listed companies in Tehran Stock Exchange. Journal of Accounting Research, 2, 50-71.

Noravesh, I., \& Saidi, A. (2007). Evaluation of comprehensive income superiority to net income to evaluate the firm performance. Master Thesis, Science and Research university, Tehran.

Pareja, I.V. (2010). Cost of capital depends on free cash flow. The IUP Journal of Applied Finance, 16(1), 27-39.

Platt, H., Demirkan, S., \& Platt, M. (2010). Free cash flow, enterprise value, and investor caution. The Journal of Private Equity, 13(4), 42-50.

Rahmani, A., \& Tahany, M. (2007). The ability of financial statements items in forecasting future cash flow. Master Thesis, Tehran University.

Rashidi, M. (2000). Risk Management. Shabek publication.

Rezvani Raz, K., Rekabdar, G., \& Ahmadi Ramezan, M. (2009). The review of relationship between free cash flow and dividend distribution policy of listed companies in Tehran Stock Exchange. Quarterly Journal of Financial Accounting, 1(4), 92-107

Saghafi, A., Khaleghi Moghaddam, H., \& Fadaii, H. (2007). Choosing efficient model for forecasting cash flows based on a comparison of related models. Tarbiat Modares University, Tehran.

Shariat Panahi, M., Barzide, F., \& Zamari, R. (2007). The relationship between financial ratios based on cash flow and stock return in Tehran Securities Market. Master Thesis, Tehran University.

Sheri, S., Rahmani, A., \& Salehion, M. (2007). The relationship between of earnings, cash flows and stock returns. Master Thesis, Tarbiat Modares University, Tehran.

Tehrani, R., \& Hesarzade, R. (2009). The impact of free cash flows and financing constraints on over investment and low investment, Master Thesis, Tehran University.

Tehrani, R., \& Seraji, H. (2009). The relationship between economic value added, cash flow from operating activities and profit before interest and taxes and market values of shares of listed companies in Tehran Stock Exchange. Master Thesis, Tarbiat modares University. 